\title{
Pengaruh Kepemimpinan Visioner Dan Motivasi Kerja Terhadap Kepuasan Kerja
}

\author{
(Studi pada Dosen Tetap Program Studi Perhotelan Perguruan Tinggi \\ Swasta Kota Bandung)
}

Erie Hidayat Sukriadi

Akparindo Bandung

Email: rie86.hidayat@gmail.com

\begin{abstract}
The purpose of this research is to analyze the influence of leader's visionary leadership and work motivation together towards lecturer job satisfaction in the Private Universities Hospitality Study Program in Bandung. The method used in this research is survey method with the level of explanation is associative. The Respondents in this research is using census with total of respondents are 57 respondents. The Data collection techniques are using literature study, study of documentation, and field studies using interviews and questionnaires. The Data analysis technique are using qualitative analysis and statistical analysis. Qualitative analysis includes scores of respondents, while the statistical analysis includes the path analysis. The result of this research shows that the influence of the leader's visionary leadership and work motivation together towards is at 59,23\%.
\end{abstract}

Keywords—Visionary Leadership, Work Motivation, Job Satisfaction.

Abstrak-Penelitian ini bertujuan untuk pengaruh kepemimpinan visioner pimpinan dan motivasi kerja secara bersama-sama terhadap kepuasan kerja di PTS Prodi Perhotelan Kota Bandung. Metode yang digunakan dalam penelitian ini adalah metode survey dengan tingkat eksplanasi asosiatif. Responden dalam penelitian ini merupakan sensus sebanyak 57 responden. Teknik pengumpulan data menggunakan studi kepustakaan, studi dokumentasi, dan studi lapangan menggunakan cara wawancara dan angket. Teknik analisis data yang digunakan adalah analisis kualitatif dan analisis statistik. Analisis kualitatif meliputi skor responden, sedangkan analisis statistik meliputi analisis jalur. Hasil penelitian ini menunjukkan bahwa pengaruh kepemimpinan visioner pimpinan dan motivasi kerja secara bersama-sama terhadap kepuasan kerja adalah sebesar 59,23\%.

Kata kunci-Kepemimpinan Visioner, Motivasi Kerja, Kepuasan Kerja.

\section{PENDAhUluan}

Seiring dengan perkembangan dunia pariwisata yang ditandai dengan banyaknya hotel-hotel yang didirikan, maka dari itu perlu adanya tenaga-tenaga yang profesional tersedia dibidangnya. Hal ini perlu dukungan dari dari lembaga-lembaga pendidikan khususnya bidang perhotelan untuk menyediakan tenaga-tenaga profesional tersebut. Yang terlibat untuk menghasilkan tenaga-tenaga professional tersebut dalam lembaga pendidikan adalah dosen. Dosen merupakan suatu unsur pendidikan yang sangat strategis dalam menciptakan pendidikan yang berkualitas dan juga dapat meningkatkan citra perguruan tingginya yang menauinginya. Partisipasi dan peran aktifnya memberi sumbangan besar dalam mencapai tujuan pendidikan secara nasional. Untuk itu, peningkatan kinerja dosen disuatu program studi merupakan kebutuhan yang harus ditingkatkan. Dalam Undang-Undang Nomor 20 Tahun 2003 (bab 3 pasal 7), dosen adalah tenaga profesional yang melaksanakan pekerjaan khusus, dan memiliki prinsip-prinsip:

1. Bakat, minat, panggilan jiwa, dan idealisme,

2. Komitmen untuk meningkatkan mutu pendidikan, keimanan, ketakwaan, dan akhlak mulia,

3. Kualifikasi akademik dan latar belakang pendidikan sesuai dengan bidang tugas,

4. Kompetensi yang sesuai dengan bidang tugas,

5. Tanggung jawab atas pelaksanaan tugas keprofesionalan,

6. Memperoleh penghasilan yang ditentukan sesuai dengan prestasi kerja,

7. Kesempatan untuk mengembangkan keprofesionalan secara berkelanjutan dengan belajar sepanjang hayat, 
8. Jaminan perlindungan hukum dalam melaksanakan tugas keprofesionalan,

9. Organisasi profesi yang mempunyai kewenangan mengatur hal-hal yang berkaitan dengan tugas keprofesionalan dosen.

Untuk meningkatkan kinerja dosen diperlukan aktivitas yang terencana dari lembaga yang bersangkutan. Adapun cara yang dapat dilakukan oleh lembaga perguruan tinggi: (1) meningkatkan kualitas hubungan antara atasan dan bawahan lembaga pendidikan, (2) meningkatkan komitmen dosen terhadap profesinya dan (3) mengefektifkan kepemimpinan dalam pendidikan. Sebagaimana dikatakan Mahmudi (2007: 20) yang menyebutkan beberapa faktor yang dapat mempangaruhi kinerja antara lain:

1. Faktor personal/individual, meliputi: pengetahuan, ketrampilan (skill), kemampuan, kepercayaan diri, motivasi dan komitmen.

2. Faktor kepemimpinan, meliputi kualitas dalam memberikan dorongan, semangat, arahan dan dukungan yang diberikan manajer dan team leader.

3. Faktor tim, meliputi kualitas dukungan dan semangat yang diberikan oleh rekan dalam satu tim, kekompakan dan keeratan anggota tim.

4. Faktor sistem, meliputi sistem kerja dan infrastruktur yang diberikan oleh organisasi, proses organisasi, dan kultur kinerja dalam organisasi.

5. Faktor kontekstual (visioner) meliputi: tekanan dan perubahan lingkungan eksternal dan internal.

Hubungan baik antara atasan dan bawahan membuat suasana di tempat kerja menjadi menyenangkan dan kondusif. Atasan memiliki berbagai gaya dan cara dalam mengawasi pekerjaan: antara lain, ada yang menyerahkan segala sesuatunya kepada yang diberi tugas, ada yang senang memerintah, senang mengajarkan dan ada yang senang memperhatikan pekerjaan sampai detail. Atasan yang memberi kepercayaan dan kebebasan pada bawahan, tentu hanya dengan sedikit pengawasan, sangat sesuai bagi mereka yang senang bekerja secara mandiri. Jika merasa nyaman dengan cara ini dan dapat mempertanggungjawabkan kepercayaan yang diberikan, serta dapat bekerja secara mandiri, maka pendekatan ini sangat cocok bagi bawahan.

Kinerja yang bagus akan tercapai apabila pemimpin mampu mempengaruhi sumber daya manusia untuk bekerja secara efektif. Kepemimpinan yang efektif merupakan keterpaduan situasi yang akan terjadi dari hubungan pemimpin dengan dosen dalam hal ini yaitu dosen. Oleh karena itu perlu dilakukan upaya untuk menemukan kepemimpinan yang tepat dengan variabel-variabel situasi yang ada pada organisasi. Kinerja yang ditunjang oleh pengaplikasian kepemimpinan dan motivasi kerja serta kepuasan yang tepat diharapkan mampu menunjang kinerja dosen Pendidikan Tinggi Swasta yang berada di Kota Bandung. Bahkan lebih dari itu diharapkan mampu meningkatkan daya saing organisasi secara eksternal.

Penelitian ini mengenai Pengaruh dikarenakan dari teori-teori di atas diketahui bahwa kinerja melalui kepuasan kerja dipengaruhi oleh kepemimpinan dan motivasi kerja, maka dari itu penulis mencoba membuktikan kebenaran pengaruh tersebut dan mengetahui seberapa besar pengaruhnya. Sehingga jika terbukti teori tersebut benar, maka nantinya dapat dijadikan bahan pertimbangan oleh pihak terkait sebagai cara untuk meningkatkan kinerja dosen Pendidikan Tinggi Swasta Program Studi Perhotelan di Kota Bandung.

\section{KAJIAN PUSTAKA}

\section{A. Kepemimpinan Visioner}

Dalam sebuah organisasi yang formal sudah merupakan keharusan bahwa harus memiliki seorang pimpinan, dimana pimpinan tersebut mempunyai tugas dan tanggung jawab terhadap keberlangsungan suatu organisasi tersebut. Seperti yang dikutip oleh Sedarmayanti (2009:119) mengemukakan bahwa: "Pemimpin adalah sebagai seorang yang bertugas mengarahkan dan mengkoordinasi aktivitasaktivitas yang ada dalam tugas-tugas kelompok. Seorang pemimpin adalah seseorang yang karena kecakapan pribadinya dengan atau tanpa pengangkatan resmi dapat mempengaruhi kelompok yang dipimpinnya untuk mengarahkan usaha kerjasama ke arah pencapaian sasaran tertentu".

Menurut Sanusi (2009:22) Kepemimpinan Visioner, yaitu pola kepemimpinan yang ditujukan untuk memberi arti pada kerja dan usaha yang perlu dilakukan bersama-sama oleh para anggota organisasi dengan cara memberikan arahan dan makna pada kerja, dan usaha yang dilakukan berdasarkan visi yang jelas. Kepemimpinan visioner memerlukan kompetensi tertentu. Pemimpin visioner setidaknya harus memiliki 4 (empat) kompetensi sebagaimana yang dikemukakan oleh Burt Nanus dalam Sanusi (2009:21), yaitu: 
1. Seorang pemimpin visioner harus memiliki kemampuan untuk berkomunikasi secara efektif dengan manajer dan karyawan lainnya dalam organisasi.

2. Seorang pemimpin visioner harus memahami lingkungan luar dan memiliki kemampuan bereaksi secara tepat atas segala ancaman dan peluang.

3. Seorang pemimpin visioner harus memegang peran penting dalam membentuk dan mempengaruhi praktek organisasi, prosedur, produk dan jasa. Seorang pemimpin dalam hal ini harus terlibat dalam organisasi untuk menghasilkan dan mempertahankan kesempurnaan pelayanan, sejalan dengan mempersiapkan dan memandu jalan organisasi ke masa depan.

4. Seorang pemimpin visioner harus memiliki atau mengembangkan ceruk untuk mengantisipasi masa depan. Ceruk ini merupakan sebuah bentuk imajinatif, yang berdasarkan atas kemampuan data untuk mengakses kebutuhan masa depan konsumen, tekhnologi dan lain sebagainya. Hal ini termasuk kemampuan untuk mengatur sumber daya organisasi guna mempersiapkan diri menghadapi kemunculan kebutuhan dan perubahan.

Sedangkan menurut Barbara Brown dalam Sanusi (2009:23) mengajukan 10 (sepuluh) kompetensi yang harus dimiliki oleh seorang pemimpin visioner, yaitu:

1. Visualizing, pemimpin visioner mempunyai gambaran jelas tentang apa yang hendak dicapai dan mempunyai gambaran jelas kapan hal itu akan dapat dicapai.

2. Futuristic Thinking, pemimpin visioner tidak hanya memikirkan di mana posisi bisnis pada saat ini, tetapi lebih memikirkan di mana posisi yang diinginkan pada masa yang akan datang.

3. Showing Foresight, pemimpin visioner adalah perencana yang tidak hanya mempertimbangkan apa yang ingin dilakukan, tetapi mempertimbangkan tekhnologi, prosedur, organisasi dan faktor lain yang mungkin dapat mempengaruhi rencana.

4. Proactive Planning, pemimpin visioner menetapkan sasaran dan strategi yang spesifik untuk mencapai sasaran tersebut. Pemimpin visioner mampu mengantisipasi atau mempertimbangkan rintangan potensial dan mengembangkan rencana darurat untuk menanggulangi rintangan tersebut.
5. Creative Thinking, dalam menghadapi tantangan pemimpin visioner berusaha mencari alternatif jalan keluar yang baru dengan memperhatikan isu, peluang, dan masalah.

6. Taking Risks, pemimpin visioner berani mengambil resiko dan menganggap kegagalan sebagai peluang bukan kemunduran.

7. Process Alignment, pemimpin visioner mengetahui bagaimana cara menghubungkan dirinya dengan sasaran organisasi. Ia dapat segera menselaraskan tugas dan pekerjaan setiap departemen pada seluruh organisasi.

8. Coalition Building, pemimpin visioner menyadari bahwa dalam rangka mencapai sasaran, dirinya harus menciptakan hubungan yang harmoni, baik ke dalam maupun ke luar organisasi. Ia aktif mencari peluang untuk bekerjasama dengan berbagai macam individu, departemen, dan golongan tertentu.

9. Continuous Learning, pemimpin visioner harus mampu dengan teratur mengambil bagian dalam pelatihan dan berbagai jenis pengemban lainnya, baik di dalam maupun di luar organisasi. Pemimpin visioner mampu menguji setiap interaksi negatif atau positif, sehingga mampu mempelajari situasi. Pemimpin visioner mampu mengejar peluang untuk bekerjasama dan mengambil bagian dalam proyek yang dapat memperluas pengetahuan, memberikan tantangan berpikir dan mengembangkan imajinasi.

10. Embracing Change, pemimpin visioner mengetahui bahwa perubahan adalah suatu bagian yang penting bagi pertumbuhan dan pengembangan. Ketika ditemukan perubahan yang tidak diinginkan atau tidak diantisipasi, pemimpin visioner dengan aktif menyelidiki jalan yang dapat memberikan manfaat pada perubahan tersebut.

\section{B. Motivasi Kerja}

Motivasi merupakan hasil sejumlah proses yang bersifat internal atau eksternal bagi seorang individu, yang menyebabkan timbulnya sikap antusias dalam hal melaksanakan kegiatan-kegiatan tertentu. Sedangkan, motivasi kerja adalah suatu kekuatan potensial yang ada dalam diri seorang manusia, yang dapat dikembangkannya sendiri atau dikembangkan oleh sejumlah kekuatan luar yang pada intinya berkisar sekitar imbalan moneter dan nonmoneter, yang dapat mempengaruhi hasil kinerjanya secara positif atau secara negatif, hal 
mana tergantung pada situasi dan kondisi yang dihadapi orang yang bersangkutan.

Menurut Uno (2007:3) motivasi berasal dari kata motif yaitu daya penggerak dalam diri seseorang untuk melakukan aktivitas tertentu, demi mencapai tujuan tertentu. Motivasi kerja merupakan faktor penting yang mempengaruhi kinerja dosen. Motivasi kerja yang dimaksud adalah suatu dorongan mental yang muncul dari dalam dan luar diri dosen untuk melaksanakan tugas. Duncan dalam Uno (2007:87) mengemukakan motivasi kerja berkaitan dengan dorongan yang muncul dari diri seseorang untuk melakukan tugas secara keseluruhan berdasarkan tanggung jawab masing-masing (dosen). Bagi seorang dosen, tugas dan tanggung jawab tersebut terlihat dalam melaksanakan Tri Dharma Perguruan Tinggi. Diduga dosen yang mempunyai motivasi kerja yang tinggi maka akan menghasilkan kinerja yang tinggi pula.

Sedangkan menurut Edison et. al. (2017:170) motivasi yang tinggi dipengaruhi oleh beberapa alasan sehingga menimbulkan kekuatan mengarahkan perilaku seseorang agar berbuat sesuatu untuk tujuan-tujuan tertentu. Oleh sebab itu, motivasi biasa disebut sebagai pendorong atau semangat kerja. Sedangkan menurut Sutrisno Edy (2009:124), dimensi motivasi kerja terbagi menjadi dua, yaitu: a. Faktor Internal: keinginan untuk hidup, penghargaan, pengakuan. b. Faktor Ekternal: kondisi lingkungan kerja (cahaya yang cukup, bersih, strategis), adanya jaminan pekerjaan. Berikut pada gambar 1 adalah hierarki kebutuhan menurut Maslow dengan penjelasan:

1. Physiological needs, kebutuhan fisiologis. Yang termasuk kelompok ini adalah kebutuhan yang paling dasar, seperti mendapatkan makanan, air, udara, istirahat, dan hubungan seksual. Kebutuhan dasar ini muncul lebih dulu sebelum keinginan pada jenjang kedua, yaitu kebutuhan akan rasa aman.

2. Safety needs, atau security needs, kebutuhan akan rasa aman mencakup semua kebutuhan terhadap lingkungan yang aman dan terlindungi. Baik secara fisik maupun emosi, serta bebas dari ancaman termasuk lingkungan yang tertib dan kemerdekaan dari tindak kekerasan. Dalam lingkup dunia kerja, kebutuhan ini terrefleksikan menjadi keamanan kerja, pungutan liat, dan jenis pekerjaan yang aman, jaminan haari tua, dan kebutuhan masa pension nanti.

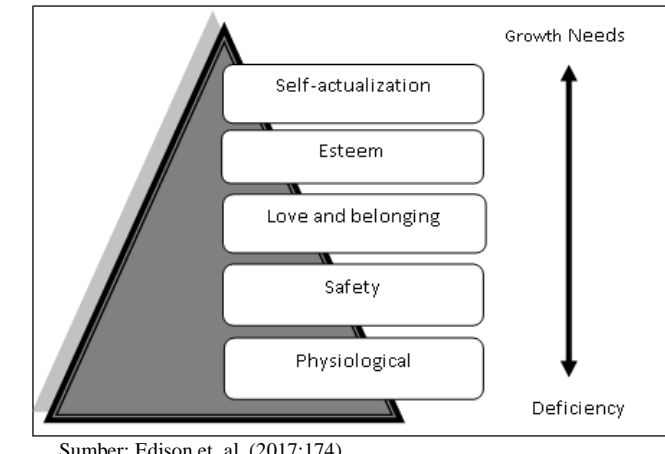

GAMBAR 1

HIERARKI KEBUTUHAN MASLOW

3. Affection needs atau love needs atau belonging needs, kebutuhan untuk disukai (rasa memiliki, social, dan cinta) merupakan kebutuhan yang lebih tinggi, setelah terpenuhi kebutuhan dasar fisik dan rasa amannya.

4. Esteem needs, kebutuhan harga diri. Pada tinggkat ini, individu memiliki kebutuhan untuk prestasi dan mandapatkan pengakuan serta penghargaan dari orang lain.

5. Self-actualization needs, kebutuhan pengembangan diri atau aktualisasi diri. Ini merupakan kebutuhan pada hierarki tertinggi, yaitu memenuhi diri sendiri dengan memaksimalkan keahlian dan potensi yang ada.

\section{Kepuasan Kerja}

Menurut pendapat Robbins dalam Situmorang dan Sarjono (2013) kepuasan kerja sebagai suatu sikap umum seseorang individu terhadap pekerjaannya. Berdasarkan pendapat Siagian (2009:295) kepuasan kerja merupakan suatu cara pandang seseorang baik yang bersifat positif maupun yang bersifat negatif tentang pekerjaannya. Suatu perasaan positif tentang pekerjaan seseorang yang merupakan hasil dari sebuah evaluasi karakteristiknya (Robbins \& Judge, 2008:107) Sedangkan menurut Edison dkk (2017:210) menyebutkan: "Robbins \& Coulter (2009:301) menyebutkan bahwa, “ a job satisfaction refers to a person general attidute toward or job" (kepuasan kerja merupakan sikap umum seseorang terhadap pekerjaannya).
D. Faktor yang Mempengaruhi Kepuasan Kerja

Menurut Robbins dan Judge (2007:81) Dimensi Kepuasan Kerja terdiri atas: 


\section{Pekerjaannya (Work It Self)}

Suatu pekerjaan memerlukan suatu keterampilan tertentu sesuai dengan bidangnya masing - masiing. Sukar tidaknya suatu pekerjaan serta perasaan seseorang bahwa keahliannya dibutuhkan dalam melakukan pekerjaan tersebut, akan meningkatkan atau mengurangi kepuasan kerja. Indikatornya adalah jenis pekerjaan.

\section{Gaji (Pay)}

Salah satu faktor pemenuhan kebutuhan hidup pegawai yang dianggap layak atau tidak. Indikatornya adalah tingkat gaji dan tingkat reward.

\section{Supervisi/Atasan (Supervision)}

Atasan yang baik artinya mau menghargai pekerjaan bawahannya. Bagi bawahan, atasan bisa dianggap sebagai figur ayah/ibu/teman dan sekaligus atasannya. Indikatornya adalah sikap atasan dan gaya kepemimpinan.

4. Rekan Kerja (Co-worker)

Faktor yang berhubungan dengan hubungan antara pegawai dengan atasannya dan dengan hubungan pegawai lain, baik yang sama maupun yang berbeda jenis pekerjaaanya. Indikatornya adalah sikap rekan kerja.

\section{METODE PENELITIAN}

Metode yang digunakan dalam penelitian ini adalah metode survey dengan tingkat eksplanasi asosiatif. Responden dalam penelitian ini merupakan sensus sebanyak 57 responden. Teknik pengumpulan data menggunakan studi kepustakaan, studi dokumentasi, dan studi lapangan menggunakan cara wawancara dan angket. Teknik analisis data yang digunakan adalah analisis kualitatif dan analisis statistik. Analisis kualitatif meliputi skor responden, sedangkan analisis statistik meliputi analisis jalur

Lokus penelitian ini dilakukan pada dosen tetap yayasan prodi perhotelan Perguruan Tinggi Swasta di Kota Bandung yang berada pada naungan Kementristekdikti. Analisis deskriptif terdiri atas penyajian data dengan tabel hasil pengolahand an analisis inferensial (uji hipotesis) dengan analisis jalur.

Sebelumnya perlu dilakukan uji persyaratan analisis data, yaitu, uji normalitas, uji linearitas, dan signifikansi regresi. Semua pengujian statistik menggunakan tingkat signifikansi $\alpha=$ 0,05

Uji statistik yang harus dipenuhi dalam analisis jalur (path analysis) adalah: uji validitas, uji reliabilitas, uji normalitas, uji homogenitas, uji linearitas, dan signifikansi model regresi.

\section{Uji Validitas}

Pengujian validitas terhadap 10 item angket untuk variabel $\mathrm{X} 1$ yaitu tingkat kepemimpinan visioner menunjukkan semuanya dinyatakan valid dengan hasil semua skor diatas $0,6>0,4$ yaitu $\mathrm{r}$ hitung $>\mathrm{r}$ tabel. Pengujian validitas terhadap 7 item angket untuk variabel $\mathrm{X} 2$ yaitu variabel motivasi kerja menunjukkan semuanya dinyatakan valid dengan hasil semua skor diatas $0,6>0,4$ yaitu $\mathrm{r}$ hitung $>\mathrm{r}$ tabel. pengujian validitas terhadap 11 item angket untuk variabel Y yaitu variabel dan kepuasan kerja menunjukkan bahwa semuanya dinyatakan valid dengan hasil semua skor diatas 0,5 > 0,4 yaitu $r$ hitung $>r$ tabel.

\section{Uji Reliabilitas}

Sugiyono (2008:121) menyatakan bahwa "instrumen yang reliabel adalah instrumen yang bila digunakan beberapa kali untuk mengukur obyek yang sama akan menghasilkan data yang sama". Hasil uji reliabilitas variabel X1, X2, Y dan $\mathrm{Z}$ menunjukkan bahwa keempatnya dinyatakan reliabel

\section{Uji Normalitas}

uji normalitas ini mengunakan rumus Kolmogorov Smirnov SPSS 19.00 dan hasilnya adalah nilai KSZ sebesar 0.664 dan Asymp Sig sebesar 0.770 lebih besar dari 0.05 , yang berarti bahwa data berdistribusi normal. Berarti asumsi normalitas data terpenuhi

\section{Uji Homogenitas}

Pengujian homogenitas varians mengasumsikan bahwa skor setiap variabel memiliki varians yang homogen. Pengujian homogenitas disini menggunakan Uji Barlett, dimana kriteria yang digunakan adalah apabila nilai hitung $\chi^{2}>$ nilai tabel, maka H0 menyatakan varians skornya homogen ditolak, dalam hal lainnya diterima. Berdasarkan hasil pengujian homogenitas dengan menggunakan uji Barlett, diketahui nilai hitung $\chi 2=-65,222<$ $\chi 2=5,991$, sehingga kesimpulannya variasi data dalam penelitian ini dinyatakan homogen

\section{Uji Lineritas}

Pemeriksaan kelinieran regresi dilakukan melalui pengujian hipotesis nol, bahwa regresi linier melawan hipotesis tandingan bahwa regresi tidak linier.

a. Hasil Uji Linieritas Data Variabel X1 atas Variabel Y

Hasil perhitungan uji linieritas data variabel kepemimpinan visioner pimpinan (X1) atas data variabel kepuasan kerja (Y) diketahui $\mathrm{F}$ hitung sebesar 0,3724 dan F tabel pada $\alpha=0,05$ adalah $=1,8751$. Dengan demikian F hitung < F tabel, 
artinya data kepemimpinan Visioner Pimpinan (X1) atas data variabel kepuasan kerja (Y) adalah linier.

\section{b. Hasil Uji Linieritas Data Variabel X2 atas Variabel Y}

Hasil perhitungan uji linieritas data variabel motivasi kerja (X2) atas data variabel kepuasan kerja (Y) diketahui $\mathrm{F}$ hitung sebesar 0,3367 dan $\mathrm{F}$ tabel pada $\alpha=0,05$ adalah $=1,9412$. Dengan demikian $\mathrm{F}$ hitung $<\mathrm{F}$ tabel, artinya data variabel motivasi kerja (X2) atas data variabel kepuasan kerja (Y) adalah linier.

\section{HASIL PENELITIAN DAN PEMBAHASAN}

\section{A. Karakteristik Responden}

Berdasarkan jenis kelamin sebagian besar responden adalah berjenis kelamin laki-laki yaitu sebanyak 31 orang $(54 \%)$ dan sisanya berjenis kelamin perempuan. Berdasarkan usia sebanyak 26 orang dosen tetap yang ada di Prodi Perhotelan PTS Kota Bandung berusia produktif yaitu antara 31 - 40 tahun, dan sisanya yang berusia dibawah 31 tahun sebanyak 17 orang dan diatas 40 tahun sebanyak 14 orang. Berdasarkan pendidikan diketahui bahwa dosen tetap Perguruan Tinggi Swasta Program Studi Perhotelan di Kota Bandung didominasi oleh dosen-dosen tetap yang berpendidikan S2. Berdasarkan masa kerja diketahui bahwa responden pada dosen tetap Perguruan Tinggi Swasta Program Studi Perhotelan di Kota Bandung lebih banyak yang masa kerjanya dibawah 5 (lima) tahun.

\section{B. Pengujian Hipotesis}

Analisis dalam penelitian ini menggunakan analisis jalur. Adapun hasilnya dapat dilihat pada gambar 1 berikut:

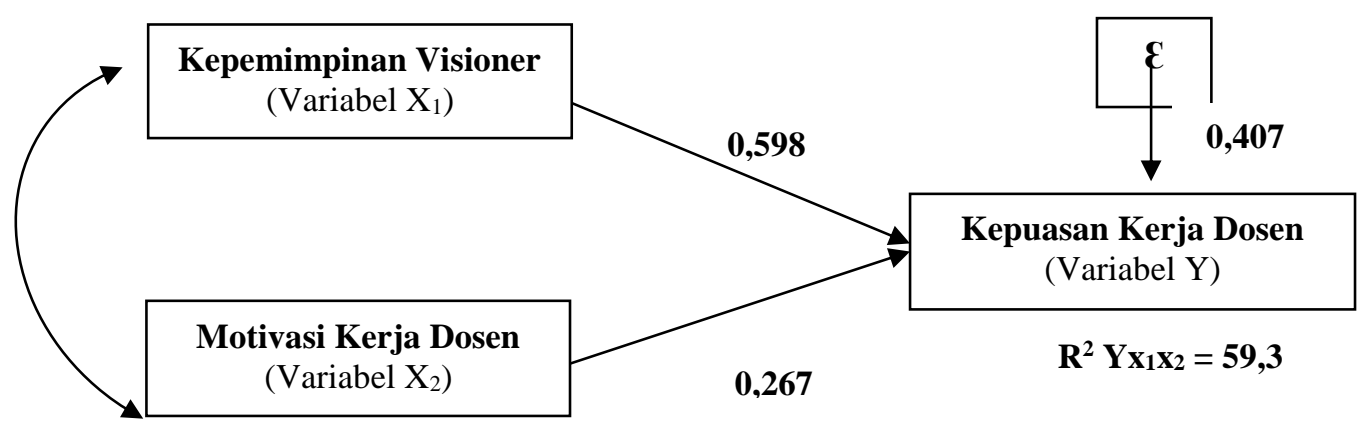

GAMBAR 1. MODEL ANALISIS JALUR

Pada gambar 1 dijelaskan bahwa masingmasing variabel yaitu kepemimpinan visioner $\left(\mathrm{X}_{1}\right)$ dan motivasi kerja dosen $(\mathrm{X} 2)$ berpengaruh terhadap kepuasan kerja dosen (Y) baik secara parsial maupun simultan. Berarti variabel kepemimpinan visioner terhadap kepuasan kerja dosen terdapat pengaruh positif baik secara langsung maupun tidak langsung melalui motivasi kerja dosen dengan total pengaruh sebesar 43,93\%, yang artinya untuk meningkatkan kepuasan kerja dosen tetap sumbangan pengaruh dari variabel kepemimpinan visioner sebanyak 43,93\%. Hal ini didukung oleh usia dosen tetap didominasi antara $31-40$ yang relatif produktif dengan masa usia mereka kurang dari 5 tahun sehingga pigur pimpinan masih banyak dilihat dan diperhatikan. Sedangkan variabel motivasi kerja terhadap kepuasan kerja meskipun pengaruhnya lebih kecil dari pada variabel kepemimpinan visioner yaitu sebesar $15,30 \%$, pengaruh tersebut merupakan pengaruh total dari pengaruh langsung dan tidak langsung melalui variabel kepemimpinan visioner. Ini berarti melihat dari karakteristik responden yang masa kerjanya rata-rata dibawah 5 tahun dan usia berada diantara 31-40 tahun, mereka belum sepenuhnya termotivasi untuk mendedikasikan diri pada perguruan tinggi tersebut sehingga pengaruhnya terhadap kepuasan kerjanya belum maksimal.

Adapun pengaruh simultan variabel kepemimpinan visioner dan variabel motivasi kerja terhadap kepuasan kerja berpengaruh positif dengan sumbangan pengaruh sebesar $59,23 \%$. Artinya di prodi perhotelan PTS Kota Bandung kepemimpinan visioner dan motivasi kerja pelaksanaanya ditingkatkan akan meningkatkan pelaksanaan dari kepuasan kerja dosen tetapnya.

\section{Pembahasan}

Berikut ini akan diuraikan pembahasan analisis sesuai dengan hipotesis yang diajukan.

\section{Pengaruh Kepemimpinan Visioner Pimpinan terhadap Kepuasan Kerja Dosen Tetap Prodi Perhotelan}

Secara empiris, hasil penelitian ini menginformasikan: (1) terdapat pengaruh yang signifikan antara kepemimpinan visioner pimpinan terhadap Kepuasan Kerja Dosen Tetap 
Prodi Perhotelan di Perguruan Tinggi Swasta Kota Bandung, serta (2) besarnya kepemimpinan visioner pimpinan terhadap Kepuasan Kerja Dosen Tetap Prodi Perhotelan di Perguruan Tinggi Swasta Kota Bandung ditunjukkan oleh hasil penelitian bahwa kepemimpinan visioner pimpinan yang terdiri dari kemampuan pimpinan dalam: visualizing, futuristic thinking, showing foresight, proactive planning, creative thinking, taking risks, process alignment, coalition building, continues learning, dan embracing change, membawa implikasi yang signifikan terhadap kepuasan kerja yang meliputi dimensi: pekerjaan itu sendiri. Namun demikian kepuasan kerja dosen tetap pada PTS Prodi Perhotelan di Kota Bandung ini tidak hanya dipengaruhi oleh kepemimpinan visioner pimpinan saja, ada faktor lain (epsilon), selain dari motivasi kerja, yang juga berpengaruh, yang tidak dikaji dalam penelitian ini.

Berdasarkan temuan empiris yang menunjukkan adanya pengaruh yang signifikan kepemimpinan visioner pimpinan dengan kepuasan kerja, maka hasil penelitian ini memberikan beberapa informasi, diantaranya: (1) kepemimpinan visioner pimpinan pada PTS Prodi Perhotelan di Kota Bandung memberikan pengaruh yang berarti terhadap kepuasan kerja, (2) salah satu cara untuk meningkatkan kepuasan kerja dosen tetap pada PTS Prodi Perhotelan di Kota Bandung adalah dengan meningkatkan kepemimpinan visioner pimpinan, serta (3) persentase pengaruh kepemimpinan visioner pimpinan terhadap kepuasan kerja secara langsung adalah sebesar $35,76 \%$, sedangkan secara tidak langsung melalui motivasi kerja sebesar $8,17 \%$ sehingga total pengaruh yang diberikan kepemimpinan visioner terhadap kepuasan kerja sebesar $43,93 \%$ sementara sisanya dipengaruhi oleh variabel lain, selain variabel motivasi kerja, yang tidak dikaji dalam penelitian ini (epsilon).

2. Pengaruh Motivasi Kerja terhadap Kepuasan Kerja Dosen Tetap.

Secara empiris, hasil penelitian ini menginformasikan: (1) terdapat pengaruh yang signifikan antara motivasi kerja terhadap kepuasan kerja dosen tetap pada PTS Prodi Perhotelan di Kota Bandung, serta (2) besarnya pengaruh motivasi kerja terhadap kepuasan kerja dosen tetap pada PTS Prodi Perhotelan di Kota Bandung ditunjukkan oleh hasil penelitian bahwa motivasi kerja yang terdiri dari dimensi: kebutuhan fisiologis, kebutuhan rasa aman, kebutuhan untuk disukai, kebutuhan harga diri dan kebutuhan pengembangan diri membawa implikasi yang signifikan terhadap kepuasan kerja yang meliputi dimensi: pekerjaan itu sendiri. Namun demikian kepuasan kerja dosen tetap pada PTS Prodi Perhotelan di Kota Bandung ini tidak hanya dipengaruhi oleh motivasi kerja saja, ada faktor lain (epsilon), selain dari kepemimpinan visioner pimpinan, yang juga berpengaruh, yang tidak dikaji dalam penelitian ini.

Berdasarkan temuan empiris yang menunjukkan adanya pengaruh yang signifikan motivasi kerja dengan kepuasan kerja, maka hasil penelitian ini memberikan beberapa informasi, diantaranya: (1) motivasi kerja pada PTS Prodi Perhotelan di Kota Bandung memberikan pengaruh yang berarti terhadap kepuasan kerja, (2) salah satu cara untuk meningkatkan kepuasan kerja pada PTS Prodi Perhotelan di Kota adalah dengan meningkatkan motivasi kerja, serta (3) persentase pengaruh motivasi kerja terhadap kepuasan kerja secara langsung adalah sebesar $7,13 \%$ sedangkan pengaruh tidak langsung melalui kepemimpinan visioner sebesar $8,17 \%$ sehingga pengaruh total motivasi kerja terhadap kepuasan kerja dosen tetap sebesar $15,30 \%$, sementara sisanya dipengaruhi oleh variabel lain, selain variabel kepemimpinan visioner pimpinan, yang tidak dikaji dalam penelitian ini (epsilon).

3. Pengaruh Kepemimpinan Visioner Pimpinan dan Motivasi Kerja Secara Bersama-sama terhadap Kepuasan Kerja Dosen Tetap.

Secara empiris, hasil penelitian ini menginformasikan: (1) terdapat pengaruh yang signifikan antara kepemimpinan visioner pimpinan dan motivasi kerja secara bersamasama terhadap kepuasan kerja dosen tetap pada PTS Prodi Perhotelan di Kota Bandung, serta (2) besarnya pengaruh kepemimpinan visioner pimpinan dan motivasi kerja secara bersamasama terhadap kepuasan kerja dosen tetap pada PTS Prodi Perhotelan di Kota Bandung ditunjukkan oleh hasil penelitian bahwa kepemimpinan visioner pimpinan yang terdiri dari dimensi: visualizing, futuristic thinking, showing foresight, proactive planning, creative thinking, taking risks, process alignment, coalition building, continues learning, dan embracing change, dan motivasi kerja yang terdiri dari dimensi: kebutuhan fisiologis, kebutuhan rasa aman, kebutuhan untuk disukai, kebutuhan harga diri, dan kebutuhan pengambangan diri membawa implikasi yang signifikan terhadap kepuasan kerja yang meliputi dimensipekerjaan itu sendiri. Namun demikian kepuasan kerja dosen tetap pada PTS Prodi Perhotelan di Kota Bandung ini tidak hanya dipengaruhi oleh kepemimpinan visioner pimpinan dan motivasi kerja saja, ada faktor lain 
(epsilon), yang juga berpengaruh, yang tidak dikaji dalam penelitian ini.

Berdasarkan temuan empiris yang menunjukkan adanya pengaruh yang signifikan kepemimpinan visioner pimpinan dan motivasi kerja secara bersama-sama terhadap kepuasan kerja, maka hasil penelitian ini memberikan beberapa informasi, diantaranya: (1) kepemimpinan visioner pimpinan dan motivasi kerja dosen tetap pada PTS Prodi Perhotelan di Kota Bandung memberikan pengaruh yang berarti terhadap kepuasan kerja, (2) salah satu cara untuk meningkatkan kepuasan kerja dosen tetap pada PTS Prodi Perhotelan di Kota Bandung adalah dengan meningkatkan kepemimpinan visioner pimpinan dan motivasi kerja dosen tetapnya, serta (3) persentase pengaruh kepemimpinan visioner pimpinan dan motivasi kerja secara bersama-sama terhadap kepuasan kerja adalah sebesar 59,23\%, sementara sisanya sebanyak $40,77 \%$ dipengaruhi oleh variabel lain, yang tidak dikaji dalam penelitian ini (epsilon).

\section{KESIMPULAN}

Berdasarkan hasil penelitian, dan pembahasan yang telah dilakukan, maka dapat diambil beberapa kesimpulan sebagai berikut; 1) terdapat pengaruh yang signifikan antara kepemimpinan visioner pimpinan terhadap kepuasan kerja dosen tetap di PTS Prodi Perhotelan Kota Bandung, 2) terdapat pengaruh yang signifikan antara motivasi kerja terhadap kepuasan kerja dosen tetap di PTS Prodi Perhotelan Kota Bandung, dan 3) terdapat pengaruh yang signifikan antara kepemimpinan visioner pimpinan dan motivasi kerja secara simultan terhadap kepuasan kerja dosen tetap di PTS Prodi Perhotelan di Kota Bandung.

Dari kesimpulan di atas, ada beberapa saran yang penulis ingin sampaikan kepada Perguruan Tinggi Swasta Prodi Perhotelan di Kota Bandung; 1) bagi pimpinan prodi perhotelan. Sesuai dengan kesimpulan bahwa pelaksanaan kepemimpinan visioner cukup efektif, akan tetapi ada beberapa indikator yang perlu adanya peningkatan yang diantaranya para pimpinan harus selalu berusaha dan tetap belajar dalam menentukan jalan alternatif/solusi apabila organisasi menghadapi hambatan. Usaha yang dapat dilakukan yaitu dalam bentuk selalu ikut serta dalam pelatihan-pelatihan, seminarseminar ataupun workshop-workshop mengenai problem solving, 2) tingkatan tertinggi motivasi menurut Abraham Moslow adalah aktualisasi diri atau kebutuhan pengembangan diri, namun berdasarkan pembahasan motivasi yang tertinggi masih berada pada kebutuhan fisiologis. Jadi penulis menyarankan kepada para pimpinan prodi perhotelan untuk dapat memotivasi para dosen tetapnya menuju tingkatan motivasi tertinggi tersebut, yaitu dengan cara memenuhi kebutuhan-kebutuhan dalam tiap tingkatannya, dan 3) kepuasan kerja dosen tetap prodi perhotelan PTS Kota Bandung yang perlu adanya pengkajian ulang yaitu mengenai kelayakan gaji yang diterima, saran penulis untuk masalah gaji adalah pihak prodi ataupun institusi harus menyesuaikan aturan penggajian dengan standar UMK setempat. Selain itu yang perlu adanya penyesuaian adalah reward, diharapkan kepada para pimpinan prodi ataupun pimpinan institusi hendaknya reward dijadikan sarana untuk memotivasi para dosen tetapnya.

\section{DAFTAR RUJUKAN}

Edi, S. (2009). Manajemen Sumber Daya Manusia Edisi Pertama. Jakarta: Kencana Praneda Media Grup

Edison, E., Anwar, Y., \& Komariyah, I. (2016). Manajemen Sumber Daya Manusia: Strategi dan perubahan dalam rangka meningkatkan kinerja pegawai dan organisasi. Bandung: Alfabeta.

Mahmudi, M. (2007). Manajemen Kinerja Sektor Publik. Akademi Manajemen Perusahaan YKPN, Yogyakarta.

Robbins, S. P., \& Judge, T. A. (2008). Perilaku organisasi. Buku 2. Jakarta: PT Indeks Kelompok Gramedia.

Robbins, S. P., \& Judge, T. A. (2007). Perilaku organisasi. Jakarta: PT Indeks Kelompok Gramedia

Sanusi, A. (2009). Kepemimpinan Sekarang dan Masa Depan dalam Membentuk Budaya Organisasi yang Efektif. Bandung: Prospect

Sedarmayanti. (2009). Sumbar Daya Manusia dan Produktivitas Kerja. Bandung: Mandar Maju

Siagian P. S. (2009). Kiat Meningkatkan Produktivitas Kerja. Jakarta: PT Rineka Cipta

Situmorang, R., Novita, S., \& Sarjono, H. (2013). Pengaruh Motivasi Kerja dan Kompensasi terhadap Kepuasan Kerja Serta Dampaknya pada Kinerja Pegawai Negeri Sipil Kantor Kecamatan Kebon Jeruk, Jakarta Barat. Jurnal Ekonomi Universitas Esa Unggul, 4(1).

Sugiyono. (2008). Metode Penelitian Kuantitatif, Kualitatif dan R\&D. Bandung: Alfabeta.

Uno, H. B. (2007). Teori Motivasi dan Pengukurannya Analisis di Bidang Pendidikan. Jakarta: Bumi Aksara 